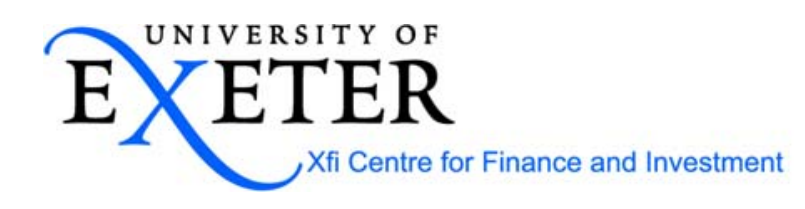

\title{
Ownership, Investor Protection and Earnings Expectations
}

\author{
Christina Dargenidou, Stuart McLeay and Ivana Raonic*
}

March 2007

Paper Number: 07/07

\begin{abstract}
This study examines the interactive influence of corporate ownership, corporate governance and investor protection on the incorporation of current value shocks in the accounting earnings of European companies. This influence is investigated not only by means of the association between current news and current earnings but also with respect to the association of the same news with expected future earnings, and its persistence. Consistent with the contractual explanation of accounting conservatism, it is shown that the accounting behaviour examined is a function of the demand created by shareholders, and that the institutional arrangements in force are of lesser significance in the presence of widely held ownership. On the other hand, greater separation between supervision and management and stronger investor protection are seen to be influential under close ownership, as these are shown to curb aggressive accounting in the form of a persistenty lower recognition of bad news in earnings. Evidence is also provided that stricter corporate governance practices in Europe can substitute for weaknesses in investor protection provisions in law.
\end{abstract}

Keywords: earnings forecasts, corporate ownership, investor protection, accounting conservatism

* The authors are respectively from the University of Exeter, the University of Wales Bangor and Cass Business School, City University. They gratefully acknowledge the helpful comments and suggestions of Miles Gietzmann, Thomas Hemmer, Thomas Jeanjean and an anonymous referee. The study forms part of the HARMONIA programme of research into accounting harmonisation and standardisation in Europe, financed by the European Commission through the Human Potential Programme HPRN-CT2000-00062.

Address for correspondence: Christina Dargenidou, Xfi Center for Finance and Investment, University of Exeter, Exeter EX4 4ST, UK. email: $\underline{\text { C.Dargenidou@exeter.ac.uk }}$ 


\section{INTRODUCTION}

The contracting explanation of conservatism suggests that accounting is a means of addressing information asymmetry amongst the various parties to the firm. In practice, accounting conservatism defers reported earnings and understates net assets, thus constraining opportunistic wealth transfers by management at the expense of other parties (Watts, 2003). Recent accounting research (Ball, Kothari and Robin, 2001; Ball, Kothari and Wu, 2003; Raonic, McLeay and Asimakopoulos, 2004; Bushman, Chen, Engel and Smith, 2004; Huijgen and Lubberink,2005; Lara, Osma and Mora, 2005;Bushman and Piotroski, 2006) has shed light on the interaction between accounting conservatism and various institutional factors that contribute to the resolution of information asymmetry between managers and shareholders. The present study considers this asymmetry as conditional on the ownership structure of firms, and examines the influence of legal arrangements for investor protection and corporate governance monitoring mechanisms on accounting conservatism. We evaluate this not only by means of the association between current news and current earnings, but also with respect to the association between the same news and future earnings in order to assess its persistence.

Most previous international accounting research in this area has examined firm level accounting behaviour using country level explanatory variables, which either characterise national institutions or measure typical behaviour in each of the countries involved. For example, the variables introduced by LaPorta et al. (1998) that are employed in an assessment of international differences in earnings management by Leuz, Nanda and Wysocki (2003) include, amongst others, types of legal system and indicators of the degree of legal enforcement in each jurisdiction. Other variables are also employed, such as total stock market capitalisation and median share ownership concentration, which aggregate or summarise at the country level economic activities that takes place at the firm level. In contrast, the present paper does not rely on aggregate level analysis in this way, but extends the model to include the appropriate

effects at the firm level. This is because the determinants of information asymmetry, such as ownership structure, vary cross-sectionally both within and between countries. 
In addition to the above, previous international research has considered a set of institutional variables that were designed primarily to address the principal-agent problem in economies with widespread corporate ownership. This disregards the possibility that jurisdictions where concentrated ownership is dominant might have developed alternative mechanisms, such as corporate governance monitoring provisions, in order to deal with the particular nature of the information asymmetries in place. Thus, in this study, the institutional arrangements that are modelled include not only legal provisions for the protection of minority shareholders, such as the antidirector rights described by LaPorta et al. (1998), but also the monitoring provisions that are set down in codes of corporate governance. Accordingly, this paper examines whether these mechanisms are substitutes, conditional on the nature of the information asymmetry that is entailed by ownership concentration.

The third contribution of the present study is to examine conservatism in a multi-period setting, building on the rationalisation of analyst forecasting in Helbok and Walker (2004). Most research in this area has focused on the contemporaneous asymmetric recognition of bad news with regards to good news. Whilst this approach provides a basis for analysing the relation between current period earnings and value shocks, it sheds no light on whether the observed relation is expected to persist. This feature of accounting conservatism is of particular interest. As Ball and Shivakumar (2005) argue, opportunistic managers not only avoid recognising the full extent of bad news in current earnings but also attempt to delay such recognition within their tenure. The extent to which such behaviour is enabled by the ownership structure of the firm and the institutional arrangements that govern it can only be tested empirically within a multi-period setting by associating current returns with current estimates of future earnings.

Rather than extracting expectations from subsequently reported earnings, we base the present study upon the observable earnings forecasts that are produced by 
analysts. ${ }^{1}$ Given that analysts try to predict the earnings figure that will be reported by the firm, it follows that accounting conservatism will be an inherent feature of the way in which such forecasts are updated. If, during the year, analysts update their forecasts of current earnings to incorporate new information, then it is likely that positive share price shocks will have less impact on the forecast of current earnings than negative shocks, although this will reverse over the forecast horizon. Consistent with this view, Helbok and Walker (2004) find that current year earnings forecasts that are produced at the time of the announcement of previous year earnings are likely to be unbiased when news during the current fiscal year is positive, and optimistic when the news during the year is negative. This implies that analysts construct their forecasts by allowing for conservatism and its eventual reversal, and it is this property of earnings forecasts that is evaluated here. ${ }^{2}$

\section{CORPORATE OWNERSHIP, INVESTOR PROTECTION AND CONSERVATISM}

Shareholders are residual claimants on the income stream generated by companies and thus are more exposed either to the diversion of corporate resources or to decisions that are not value-maximizing. ${ }^{3}$ International studies on the value relevance of

\footnotetext{
${ }^{1}$ Previously, Collins, Kothari, Shanken and Sloan (1994) have employed future reported earnings (orthogonalised with respect to future value shocks) in order to proxy for earnings expectations, although not in the context of the asymmetric recognition of bad and good news. Recent research suggests that forecasts of the current year's earnings that are produced around the fiscal year end are unbiased (Richardson, Teoh and Wysocki, 2004).

${ }^{2}$ Other research suggests a behavioural explanation for bias in analysts' forecasts, i.e. analysts have incentives to be optimistically biased which may be attributed to their business environment. However, Irvine (2004) finds that the forecast error does not boost trading volume of brokerage houses whilst optimistic recommendations do. Lin and McNichols (1998) also find no evidence that earnings forecasts by affiliated analysts for current and one year ahead earnings exhibit greater optimism than forecasts by unaffiliated analysts (where the term affiliated refers to analysts employed by a brokerage house that provides investment banking services to the firm, or has done so in the recent past).

${ }^{3}$ Lombardo and Pagano (2002) include nepotistic appointments, the pursuit of unprofitable "pet" projects, and low managerial effort amongst such decisions.
} 
financial statements (Hung, 2000) and the management of earnings (Leuz, Nanda and Wysocki, 2003) argue that accrual accounting gives managers the opportunity to mask the firm's economic performance, which may be put into effect by overstating reported earnings in order to conceal unfavourable circumstances, or by understating reported earnings in order to create reserves that will cushion negative shocks in future periods. Investor protection mechanisms address these concerns by enabling shareholders to hold managers accountable for their actions. Such mechanisms are consistent with conservative accounting, not only by forcing managers to communicate economic losses fully and in a timely manner by incorporating them in current earnings, but also by preventing them from deferring loss recognition to future periods and thereby shifting the consequences onto subsequent generations of managers (Watts 2003). The empirical findings of these studies imply also that, in weaker investor protection regimes, managers are less likely to face penalties if they behave opportunistically when making operating and financial reporting choices, and that earnings are less conservative as a result. ${ }^{4}$

In this paper, we argue that the relationship between investor protection and the financial reporting process, which impinges on the contract between shareholders and managers, is determined by the nature of information asymmetries at the firm level. ${ }^{5}$ For example, in firms with widely held shares, most shareholders rely on the financial report to provide timely information about potential losses, therefore driving the demand for conservative accounting as a means of solving the information asymmetry between them and the managers of the firm. On the other hand, in firms with closely held shares, the interests of managers and the majority shareholders are more likely to be aligned. Since those with large shareholdings may take a more active role in

\footnotetext{
${ }^{4}$ Beekes, Pope and Young (2004) have shown that conservative accounting is associated with the presence of independent executives on the boards of UK companies, evidence which points to the positive impact of governance mechanisms and not only investor protection legislation.

${ }^{5}$ In this study, the main focus is the contract between managers and shareholders. However, the contract between managers and debt holders, and possibly other stakeholders, also induces conservative accounting (Watts, 2003). Nevertheless, as debt-free firms are also subject to conservative accounting, the universal driver of accounting conservatism can be said to be the contract between shareholders and managers.
} 
management, and have access to alternative (insider) sources of information, they will rely less on financial reporting in order to monitor managers. Thus, their demand for the timely recognition of economic losses is likely to be lower. ${ }^{6}$ However, in these closely held firms, whilst the information asymmetry between majority shareholders and managers is likely to be resolved, the asymmetry will now exist between the controlling parties (i.e., the managers and majority shareholders) and outsiders (i.e., minority shareholders). Here, we argue that the extent to which information asymmetry in firms with concentrated ownership is resolved through the financial reporting process depends on whether or not the rights of minority shareholders are protected by institutional arrangements. In jurisdictions where the interests of minority shareholders are strongly protected, either by close monitoring or through legal investor protection provisions, information asymmetries are addressed in the financial reporting processes by the timely recognition of losses, and hence the negative impact of ownership concentration on conservatism should be reduced. Therefore, this study emphasises that the magnitude of the effect on accounting behaviour of institutional arrangements at the country level is conditional upon corporate ownership structures at the firm level, suggesting that their interactive effect on accounting conservatism should be investigated.

Two aspects of the institutional arrangements in place are analysed here. The first of these relates to the monitoring of managers' actions by shareholders, based on the various supervisory structures documented in national corporate governance codes (European Corporate Governance Institute, 2001). The second category includes specific provisions in company legislation that empower shareholders and which have been detailed in prior research into law and finance (La Porta et al., 1998). Table 1 provides a summary across the countries of the variables involved in the study.

\footnotetext{
${ }^{6}$ A similar argument would apply to the comparison between listed and nonlisted firms, the latter tending to concentrated ownership. Evidence of less conservatism in private firms is reported by Ball and Shivarakumar (2004) and Peek, Buijink and Coppens (2004).
} 
With regard to the monitoring of managers by shareholders, we focus on the structuring of the board of directors. A major difference among European countries relates to the use of a unitary versus a two-tier board. The unitary board structure is predominant in many countries, although in Belgium, Finland and France two-tier boards are also present and, in Germany, the Netherlands and Denmark, the two-tier structure is predominant. Generally, both the unitary board of directors and the supervisory body in the two-tier structure are elected by shareholders. Under both types of system, there is usually a supervisory function and a managerial function, although this distinction is more formalised in the two-tier structure. The unitary board and the supervisory body in the two-tier system usually appoint the members of the managerial body (either the management board in the two-tier system or a group of managers to whom the unitary board delegates authority in the unitary system), and they also have responsibility for ensuring that financial reporting and control systems are functioning properly. However, in two-tier systems, there is a more pronounced distinction between the role of the supervisory body and that of the managerial body. As we anticipate that control over the behaviour of managers will be more effective when there is a clearer distinction between the 'supervisor' and those being 'supervised', a score of 1 is assigned to a country with a predominant two-tier board structure. In addition, in countries such as Denmark, Finland, Germany, the Netherlands and Sweden, companies of a certain size and type must appoint a general manager. In such instances, there is a distinct separation between supervisory and managerial leadership, even within a unitary board (e.g. in Finland and Sweden), which should facilitate the monitoring of management by the supervisory body. Therefore, a country gets a score of 1 if there is such a requirement. As both variables described above capture the effect of corporate governance, we construct a summary indicator $C G$ that scores 1 if at least one of the above is in place in a given country and 0 if none is in place.

The second of the institutional arrangements examined in this study is the protection of investors' rights within the law. In this context, if the law in a given country grants the right to minority shareholders to challenge the decisions of the management, or if it enables minority shareholders to call a meeting or place an item on the meeting agenda, or if it allows voting by mail, or proportional representation when appointing directors to the board, investor protection is considered to be 
stronger. In such circumsatnces, a score of 1 is assigned to a particular country. As all four variables are indicators of the presence of mechanisms for the protection of outside investors, we construct a second summary indicator $I P$ that scores 1 if at least one of the mechanisms is present in a given country and 0 if none is present.

\section{CURRENT NEWS IN ANALYSTS' EARNINGS FORECASTS}

This section sets out the model employed in examining the incorporation of contemporaneous news into forward earnings. Following Pope and Walker (1999), permanent earnings for the current year are considered to be equal to permanent earnings at the beginning of the year $x_{t-1}$ plus a permanent shock $e_{t}$ that can be either positive or negative depending on the expectations of future cash flows suggested by the current set of information, i.e.

$$
x_{t}=x_{t-1}+e_{t}
$$

Furthermore, the current year's permanent earnings $x_{t}$ define the stock price when capitalised at an assumed constant discount rate $r$, as follows:

$$
P_{t}=\frac{x_{t}}{r}
$$

If reported earnings $X_{t}$ were equal to permanent earnings, then $x_{t}$ is just replaced by $X_{t}$ in equation (2). Due to accounting conservatism, however, the current year's positive value shock is not likely to increase current reported earnings. Instead, the effect will appear gradually in future reported earnings at a pace that is suggested by the accounting principles that govern the calculation of reported earnings together with any managerial discretion that is exercised. In the case of bad news on the other hand, agency costs and information asymmetries are likely to lead to immediate, and even over-cautious, recognition. As a result, reported earnings can be represented as: 


$$
X_{t}=x_{t-1}+e_{t}-\Theta e_{t}^{+}+\Gamma e_{t}^{-}+V_{t}
$$

where $X_{t}$ is reported earnings at time $t ; x_{t-1}$ is permanent earnings at time $t-1 ; e_{t}$ is the shock to permanent earnings in period $t ; \Theta$ is a parameter that captures the initial under-recognition of good news $e_{t}^{+}$in period $t ; \Gamma$ reflects the initial over-recognition of bad news $e_{t}^{-}$in period $t$; and $V_{t}$ represents the deferred effect of the gradual reversal of the conservative treatment of prior period shocks that, by assumption, are not correlated with current period shocks.

Drawing upon earnings forecasts to assess the incorporation of current news in accounting earnings in a multiperiod setting, reported earnings are replaced in this study by the earnings forecast $F_{t+n}^{(t)}$ prepared at time $(t)$ for the forward earnings period $t+n(n=0,1,2, .$.$) . An appropriate model of earnings forecasts has been$ constructed by Helbok and Walker (2004), accounting for the influence of conservatism both in terms of the initial under- and over-recognition of news as well as the reversal of this bias in subsequent periods. The Helbok-Walker model is based on the assumption that analysts are aware of the conservative nature of accounting and understand the implications of conservatism for reported earnings; and second, that analysts' forecasts are rational conditional expectations of reported earnings given the available information set at the time.

Within this general framework, the Helbok-Walker model forecasts one year ahead earnings by incorporating the reversal of conservatism in two parts. ${ }^{7}$ The first of these relates to news in $t$ - 1 , and comprises the fraction of the initial under-recognition of news in $t-1$ that is recognised in the following year when the shock to permanent

\footnotetext{
7 The model described here corresponds to Model 1 in Helbok and Walker (2004, Eq 11), which receives greater empirical support than the alternative proposal in their study. The reversal of conservatism in the year following the initial earnings shocks is denoted $\theta_{0} e_{t-1}^{+}-\gamma_{0} e_{t-1}^{-}$in the HelbokWalker model.
} 
earnings is positive, $\left(\theta_{t} e_{t-1}^{+}\right)$, or the reversal of the initial over-recognition when the shock is negative, $\left(\gamma_{t} e_{t-1}^{-}\right)$. The second component of the Helbok-Walker reversal relates to changes between $t-1$ and $t$ in the stock of conservatism that was triggered by news in all prior years ( $\left.\Delta V_{t}\right)$. Thus, the forecast of the earnings for the year $t$ made at the end of year $t-1$ is defined as:

$$
F_{t}^{(t-1)}=X_{t-1}+\left(\theta_{t} e_{t-1}^{+}-\gamma_{t} e_{t-1}^{-}\right)+\Delta V_{t}
$$

Taking account of the way in which analysts prepare their earnings forecasts, that is by allowing for the over- and under-recognition of news in earnings, it now follows from (3) that the last forecast to be made at the end of year $t$ but before the earnings for the year $t$ are disclosed, denoted $F_{t}^{(t)}$, is as follows:

$$
F_{t}^{(t)}=x_{t-1}+e_{t}-\Theta e_{t}^{+}+\Gamma e_{t}^{-}+V_{t}
$$

Likewise, the forecast of next year's earnings that is prepared at the end of the current year $F_{t+1}^{(t)}$ will be defined as:

$$
F_{t+1}^{(t)}=F_{t}^{(t)}+\left(\theta_{t+1} e_{t}^{+}-\gamma_{t+1} e_{t}^{-}\right)+\Delta V_{t+1}
$$

In the present study, it is further assumed that, in a multiperiod setting, the proportion $\Theta$ of current good news $e_{t}^{+}$that has not been captured initally by the current year forecast $F_{t}^{(t)}$ is likely to be recognised gradually in forecast earnings for future periods, i.e. in $F_{t+n}^{(t)}$, where $n \geq 1$. If $\theta_{t+n}$ is the fraction of $e_{t}^{+}$that is expected to be recognised in each of the years until $t+m$, where $n=1,2, \ldots m$, then, in the long term, the accumulation of reversals $\sum_{n=1}^{m} \theta_{t+n} e_{t}^{+}$would offset the original under-recognition 
$\Theta e_{t}^{+}$as $\sum_{n=1}^{m} \theta_{t+n} e_{t}^{+}-\Theta e_{t}^{+}$tends to zero. Negative shocks, however, tend to be either fully recognised, or even over-recognised if managers are unduly cautious. In the case of over-recognition, the initial bias $\Gamma e_{t}^{-}$is likely to be corrected by means of the reversal term $\sum_{n=1}^{m} \gamma_{t+n} e_{t}^{-}$in the near future such that $\Gamma e_{t}^{-}-\sum_{n=1}^{m} \gamma_{t+n} e_{t}^{-}$tends to zero.

It should be noted that it is not only current shocks that determine earnings expectations, and therefore we add a further component $\Delta V_{t+n}$ which denotes future reversals relating to the recognition of past shocks. ${ }^{8}$ By extending the Helbok-Walker model in this respect to more than one year ahead, forecast earnings can be described as follows: ${ }^{9}$

$$
F_{t+n}^{(t)}=F_{t}^{(t)}+\left(\sum_{n=1}^{m} \theta_{t+n} e_{t}^{+}-\sum_{n=1}^{m} \gamma_{t+n} e_{t}^{-}\right)+\Delta V_{t+n}
$$

Whereas $F_{t}^{(t)}$ incorporates the initial under- and over-recognition of current permanent earnings shocks, as shown in (5), $F_{t+n}^{(t)}$ in (7) accomodates the gradual recognition of positive shocks by adding the term $\sum_{n=1}^{m} \theta_{t+n} e_{t}^{+}$and the correction of the initial overecognition of negative shocks by substracting the term $\sum_{n=1}^{m} \gamma_{t+n} e_{t}^{-}$.

\footnotetext{
${ }^{8}$ For instance, Pope and Walker (1999) and Ryan and Zarowin (2003) provide evidence that curent earnings are associated with prior price changes dating back at least three years.

${ }^{9}$ The expected earnings process described here implies a full payout dividend policy, where earnings expectations are comparable to permanent earnings in the Hicksian sense. However, earnings forecasts will normally be drawn up on the assumption of a dividend payout of less than $100 \%$. In this case, the earnings forecast also includes a component arising from the reinvestment of prior earnings. This does not affect the inferences drawn as the reinvestment yield does not induce shocks in permanent earnings.
} 


\section{RESEARH DESIGN}

\section{Incorporation of good and bad news in earnings expectations}

If the model described above were fitted as a regression, the dependent variable would be the earnings forecast either for the current year or a future year and the explanatory variables would be present and past value shocks. Since we shall consider the effects of accounting conservatism within a three year interval, an expansion of the window beyond three years in order to allow for past price changes is not expected to contribute substantially to the evidence on conservatism reversal. Indeed, Collins et al. (1992) argue that economic events typically cause investors to revise their expectations of earnings over a relatively short horizon, with only modest revisions beyond that point. Moreover, they find little benefit from adding the fourth year's earnings growth rate in a test of association of current returns and future earnings. Thus, the regression model employed in the present study examines the association between earnings forecasts for three years and the current value shock, as follows:

$$
F Y_{i, t+n}=\alpha_{0}+\alpha_{1} R_{i t}+u_{i t}, \quad n=0,1,2
$$

where $F Y_{i, t+n}$ is the expected earnings of the $i^{\text {th }}$ firm either for the current year $(n=0)$, or for one year ahead $(n=1)$, or two years ahead $(n=2)$, scaled by market capitalisation at the beginning of the current year; and $R_{i t}$ is the annual change in market capitalisation of the $i^{\text {th }}$ firm deflated by the market capitalisation at the beginning of the current year, $\frac{M C_{t}-M C_{t-1}}{M C_{t-1}}$.

Separate regressions are fitted for positive and negative market capitalisation changes and for each $n \cdot{ }^{10}$ For positive $R$, the slope coefficient $\alpha_{1}$ in (8) will increase

\footnotetext{
${ }^{10}$ Dietrich, Muller and Riedl (2003) point out that the inclusion of a dummy variable to compare the effect of good and bad news, which is commonplace in earnings conservatism studies, introduces a bias in the error.
} 
with $n$, consistent with the positive sign of $\sum_{n=1}^{m} \theta_{t+n} e_{t}^{+}$in (7), reflecting the influence of good news that is revealed gradually and cumulatively. On the other hand, in the case of negative returns, the coefficient $\alpha_{1}$ is expected to decrease, consistent with the negative sign of $\sum_{n=1}^{m} \gamma_{t+n} e_{t}^{-}$in (7), and to do so at a faster rate, reflecting the transitory character of bad news over-recognition in a going concern firm.

\section{Interaction effects}

The full model describes the effect on conservatism of the presence within the jurisdiction where the firm is domiciled of strong investor protection mechanisms and/or a governance structure that separates monitoring from management, conditional upon the ownership of the firm. Thus, the full model must allow for the interaction of such institutional effects at the country level with a measure of ownership structure at the firm level. The specification of these variables is discussed below.

First, in order to model the institutional arrangements described in this study, we employ a factorial design where the coding scheme $k$ specifies four levels, as follows:- $(k=1,1)$ if the firm operates in an environment where strong investor protection is imposed by law and where managerial monitoring is also provided for in the local corporate governance code; $(k=1,0)$ if there is strong investor protection but no monitoring; $(k=0,1)$ if there is monitoring but investor protection is weak; and $(k=0,0)$ if neither is adequate. In this way, accounting conservatism under these different combinations of investor protection and corporate governance is described by the interaction of the factor $I P C G_{k}$ and the scaled value shocks $R_{i t}$. That is, from (8), we have 


$$
F Y_{i, t+n}=\alpha_{0}+\alpha_{1} R_{i t}+\alpha_{2 k} I P C G_{k}+\alpha_{3 k} I P C G_{k} * R_{i t}+u_{i t}, \quad n=0,1,2
$$

Note that $I P C G_{k}=0,0$ is considered here as the reference group, with all effects that are attributable to the presence of either strong investor protection or clearly defined monitoring provisions being incremental thereto. ${ }^{11}$

Second, as previous studies provide evidence that ownership concentration is related to investor protection and board characteristics (see Denis and Sarin, 1999; and La Porta et al., 1998, 1999), and as these are the proposed independent variables in our own research design, it should be recognised that ownership concentration is likely to be determined in part by the institutional arrangements surrounding the firm, and, therefore, is most probably partially endogenous. ${ }^{12}$ In order to eliminate any endogenous bias from the right-hand side variables, we employ an approach similar to that in Denis and Sarin (1999), that is a two-stage procedure where in the first stage ownership is orthogonalized with respect both to $I P C G_{k}$ and to the size effect proxied by market capitalization $\left(M C_{i t}\right)$. The orthogonalized value of ownership is then included as a separate independent variable in the second stage regression, as follows:

$$
O C_{i t}=\beta_{0}+\beta_{1 k} I P C G_{k}+\beta_{2} M C_{i t}+\varepsilon_{i t}
$$

The residual term in (10) is the component of $O C$ that is not determined by the combinations of institutional arrangements $I P C G_{k}$ and is therefore exogenous to the second stage interactions model. Defining the exogenous ownership effects as $O C^{\prime}=$ $\varepsilon_{i t}$, the extension of (10) to incorporate the ownership effect leads to:

\footnotetext{
${ }^{11}$ In a generalised linear model, $I P C G_{k}$ may be incorporated as a single factor with four nominal levels, which is the convention adopted here, or as two interacting factors $I P$ and $C G$ with two levels each. Alternatively, in an ordinary least squares regression, each of the four levels could be represented by a dummy variable.

${ }^{12}$ Denis and Sarin (1999) provide evidence that firms can exhibit significant changes in ownership and board structure in any given year and that these changes are correlated with one another representing discrete shifts in ownership structure and board composition. The evidence from La Porta et al. (1998, 1999) demonstrates that, in countries with poor anti-director protection, shareholders need to own more capital to be able to exercise their rights.
} 


$$
\begin{aligned}
F Y_{i, t+n}=\alpha_{0} & +\alpha_{1} R_{i t}+\alpha_{2 k} I P C G_{k}+\alpha_{3 k} I P C G_{k} * R_{i t}+\alpha_{4} R_{i t} * O C_{i t}^{\prime} \\
& +\alpha_{5 k} I P C G_{k} * O C_{i t}^{\prime}+\alpha_{6 k} I P C G_{k} * R_{i t} * O C_{i t}^{\prime}+\alpha_{7} M C_{i t}+u_{i t}
\end{aligned}
$$

The coefficients $\alpha_{0}$ to $\alpha_{3}$ describe the institutional effects on firms that are widely held. With respect to accounting conservatism, $\alpha_{1}$ captures the timeliness of earnings when there is no close holding of shares, weak investor protection and no governance requirements for separate monitoring, and $\alpha_{3 k}$ describes the incremental effect on timeliness of either stronger investor protection, or clearly defined monitoring mechanisms, or both. The intercept $\alpha_{0}+\alpha_{2 k}$ predicts expected earnings under each of the $I P C G_{k}$ combinations $(0,0 ; 1,0 ; 0,1 ; 1,1)$ when the value shock is zero. As a wide shareholder base is expected to increase demand for timely information, it follows that institutional arrangements are likely to be less influential in this respect, which implies insignificant $\alpha_{3 k}$ coefficients. Such a finding would have notable implications for the interpretation of prior evidence of more pronounced conservatism in countries where the investor base is more widespread (e.g. the US and UK), as this would show that conservative accounting is driven by the demand created by shareholders rather than by regulatory devices.

The coefficients $\alpha_{4}$ to $\alpha_{6}$ model the interactions between increasing ownership concentration and the institutional environment described above, and the magnitude of these coefficients indicates how the nature of information asymmetry varies with insider involvement. A negative sign on $\alpha_{4}$ would suggest that, when investor protection is weak and corporate governance does not separate supervision from management, the more closely held the firm's ownership, the more managers are likely to defer the recognition of bad news to the future. To the extent that corporate laws or governance codes prove to be effective in preventing aggressive reporting by managers when the economic performance of the firm is weak, this will be reflected in a postive interaction effect $\alpha_{6 k}$ that offsets the adverse effects of insider control captured in the negative sign of $\alpha_{4}$. Furthermore, the delay in reporting economic underperformance should also manifest itself in a negative $\alpha_{4}$ that persists across the forecast horizon, whilst the institutional pressure to counteract such behaviour should be reflected in positive $\alpha_{6 k}$ across the horizon.

On the other hand, there are no strong arguments with respect to the effects of 
investor protection, corporate governance and ownership structure on the timeliness of earnings in the presence of positive value shocks, as accounting conservatism contends with wealth decreases rather than wealth increases. As mentioned earlier, the recognition of positive shocks is expected to be less pronounced, but there is no reason why such recognition should vary in accordance with information asymmetries.

\section{ANALYSIS}

\section{Data}

The sample consists of data relating to firms that are domiciled in Belgium, Denmark, Finland, France, Germany, Italy, Netherlands, Norway, Spain, Sweden, and the UK. These are the European countries for which the full set of institutional indicators is available from the sources employed. The study treats the sample as representative of the European financial market, rather than different segmented economies, given the economic integration that has taken place during the last decade.

The data sources are $\mathrm{I} / \mathrm{B} / \mathrm{E} / \mathrm{S}$ for earnings forecasts for the current year and one and two years ahead and the corresponding number of shares for each firm, and Worldscope for market capitalisation and the information required to calculate the percentage of closely held shares ${ }^{13}$. Market capitalisation is required in order to calculate ex-dividend returns and to deflate earnings forecasts, which are specified for the purposes of this study on the entity basis rather than on the per share basis. ${ }^{14}$

\footnotetext{
${ }^{13}$ The definition of closely held shares by Worldscope is as follows: (1) shares held by officers, directors and their immediate families; (2) shares held in trust; (3) shares of the company held by any other corporation (except shares held in a fiduciary capacity by banks or other financial institutions); (4) shares held by pension/benefit plans; (5) shares held by individuals who hold 5\% or more of the outstanding shares.

${ }^{14}$ Earnings forecasts are calculated by multiplying the $\mathrm{I} / \mathrm{B} / \mathrm{E} / \mathrm{S}$ forecast per share by the number of shares in issue. This approach provides more readily for control over data equivalence, and avoids the 
All firms included have a December year-end. Since the research is international, the focus on a particular date ensures that all observations are produced under similar market conditions, albeit in different locations. However, some firms draw up their accounts for a fiscal year other than the calendar year, which is a more prevalent practice in the UK than elsewhere. Although we are unaware of evidence that might suggest that there is any temporal bias in close of year analysts' forecasts, we acknowledge that this is a potential source of concern when interpreting the results.

Finally, in order to control for the influence of extreme values, observations falling at the top and bottom $1 \%$ of the frequency distribution were deleted. The fifteen-year period from 1988 to 2002 yielded 11,769 firm-year observations.

Table 2 provides an overview of returns and expected earnings yields, by year and for the pooled sample. For the average European firm in the sample, the annual share price change was $9.07 \%$, and earnings yield forecasts were $5.61 \%$ for the same period, $7.33 \%$ for the year ahead and $8.86 \%$ for two years ahead. Annual share price changes during this period were at their lowest on average amongst German firms, whose forecast earnings were also the lowest on average. Companies domiciled in Spain and the Netherlands recorded relatively high share price changes and earnings forecasts on average. It should be noted, however, that the standard deviations of annual returns and forecast earnings yield reported in Table 2 indicate that variability across firms is a particularly important characteristic of these data, regardless of corporate domicile.

\section{Empirical results}

The model has been estimated using a cross-sectional fixed year effects regression, where the panel structure of the data through time is accounted for in the estimation

problems that occur due to the disagreement between 'per share' adjustment factors in the different databases. 
procedure. Year effects are considered appropriate to capture variation in earnings yield that could be attributed to changes in accounting conservatism and in the cost of capital across time. Indeed, changes in discount rates have been associated with more pronounced conservatism in the US by Ryan and Zarowin (2003). ${ }^{15}$ There is already evidence in the EU of an increase in earnings conservatism in the late 1990s (Raonic et al., 2004). In general, estimation of a cross-sectional time-series model with fixed effects is warranted by the high F-statistics reported in Table 3, Panel A. A random effects estimator would be inappropriate given the imbalance between groups.

Panel B of Table 3 sets out the results from regression (11) for negative changes in the market value of equity. A reduction in the effect of bad news on forward earnings expectations is evident in the decrease in the magnitude of the slope coefficient $\alpha_{1}(0.0899)$ for the current year's expected earnings with respect to the forecasts one and two years ahead (0.0784 and 0.0783), which is consistent with bad news being transient and likely to reverse in future periods.

The evidence also shows, as predicted, that institutional arrangements have very little effect on solving the information asymmetry problem in widely-held firms. Insignificant coefficients are reported for $\alpha_{3}$ in jurisdictions that rely solely on strong investor protection law $\left(\alpha_{3}(1,0)\right.$ ), and in those where corporate governance arrangements are the predominant form of regulatory pressure $\left(\alpha_{3(0,1)}\right)$, and also when both types of institutional arrangement are in place $\left(\alpha_{3(1,1)}\right.$ for current and one year ahead forecasts).

On the other hand, as insiders become more prevalent, investor protection and monitoring are called upon to address the information asymmetry that arises. Indeed, the findings show that there is a strong association between increasing ownership concentration and less timely incorporation of bad news into forward earnings, as $\alpha_{4}$ remains negative and significant across the forecaast horizon, not only in the current

\footnotetext{
${ }^{15}$ Country differences in earnings forecast methods are difficult to assess as little is known with respect to the way in which analysts form their forecasts beyond stripping extraordinary items from earnings. Also, the earnings expectation employed is the consensus (median) forecast.
} 
year (-0.0022) but also one year ahead (-0.0013) and two years ahead (-0.0012). This implies that, when the institutional constraints are limited, it is easier for insiders such as controlling shareholders and managers to conceal unfavourable information, to defer economic losses and to enjoy private control benefits. However, this negative effect is mitigated once we allow for the interaction between ownership concentration and either investor protection or monitoring. The absorption of bad news in earnings is more timely in those European jurisdictions with stronger investor protection $\left(\alpha_{6}\right.$ $(1,0)$ is positive and significant across the forecast horizon: $0.0023>0.0012>0.0011)$ and in those with more clearly defined corporate governance structures $\left(\alpha_{6(0,1)}\right.$ is also positive and significant across the forecast horizon: $0.0017>0.0014>0.0013$ ). This suggests that stricter corporate governance practices can substitute for weaknesses in investor protection provision through the law. However, when strong investor protection and well defined monitoring mechanisms are both in place, there are no offsetting or incremental interaction effects.

The evidence from Panel $\mathrm{C}$ of Table 3 shows that good news is revealed slowly and gradually in earnings forecasts, with $\alpha_{1}$ being plausibly zero in the current year but significantly positive one year and two years ahead and increasing in magnitude over time $(0.0064<0.0152<0.0275)$. The differences in ownership concentration across firms do not seem to matter when it comes to the recognition of economic gains. The estimates of $\alpha_{4}$ are insignificant, as are those of $\alpha_{5}$ and $\alpha_{6}$ which confirm the arguments advanced here regarding the influence of investor protection and corporate governance mechanisms on timeliness. These results corroborate the initial motivation to focus attention on the timely revelation of bad news, which is based on the assumption that agency issues mainly arise from insiders concealing potential losses of value.

\section{CONCLUSION}

This study analyses the interactive influence of ownership concentration, legislation that protects outside investors and corporate governance mechanisms that require a clear separation between supervision and management on the recognition of good and 
bad news in earnings forecasts. When investor protection is weak and corporate governance does not separate supervision from management, the findings show a systematic understatement in the recognition of bad news, evidence that can be interpreted as insiders (such as controlling shareholders and managers) concealing the effect of unfavourable information on current and short term earnings expectations. However, further analysis shows that effective investor protection legislation and well defined monitoring structures are able to offset these adverse effects of insider control. Also, our results suggest that corporate governance practices substitute for the lack of investor protection and vice versa. 


\section{REFERENCES}

Ball, R., S. Kothari and A. Robin (2000), 'The Effect of International Institutional Factors on Properties of Accounting Earnings', Journal of Accounting and Economics, Vol. 29 No. 1 (February), pp. 1-51.

Ball, R., A. Robin and J. Wu (2003), 'Incentives versus Standards: Properties of Accounting Income in Four East Asia Countries', Journal of Accounting and Economics, Vol. 36 Nos. 1-3 (December), pp. 235-270.

Ball, R. and L. Shivakumar (2005), 'Earnings Quality in U.K. Private Firms: Comparative Loss Recognition Timeliness', Journal of Accounting and Economics, Vol. 39 No. 1 (February), pp. 83-128.

Beekes, W., P. Pope and S. Young (2004), 'The Link Between Earnings Timeliness, Earnings Conservatism and Board Composition: Evidence from the UK', Corporate Governance: An International Review, Vol. 12, No. 1 (January), pp.47-55.

Bushman, R., Q. Chen, E. Engel and A. Smith (2004), 'Financial Accounting Information, Organizational Complexity and Corporate Governance Systems', Journal of Accounting and Economics, Vol. 37, No. 2 (June), pp.167-201.

Bushman, R. and J. Piotroski (2006), 'Financial Reporting Incentives for Conservative Accounting: The Influence of Legal and Political Institutions', Journal of Accounting and Economics, Vol. 42, Nos. 1\&2 (October), pp.107-148

Collins D., S. Kothari, J. Shanken and R. Sloan (1994), 'Lack of Timeliness and Noise as Explanations for the Low Contemporaneous Return-Earnings Association', Journal of Accounting and Economics, Vol. 18, No. 3 (November), pp. 289-324.

European Comission, Internal Market Directorate General (2002), "Comparative Study Of Corporate Governance Codes Relevant to the European Union And Its Member States"

Denis, D. and A. Sarin (1999), 'Ownership and Board Structures in Publicly Traded Corporation', Journal of Financial Economics, Vol. 52, No. 2 (May), pp. 187-223

Dietrich, J., K. Muller and E. Riedl (2003), 'Using Stock Returns to Determine 'Bad' versus 'Good' News to Examine the Conservatism of Accounting Earnings', Working Paper, The Pennsylvania State University.

Heidrick \& Struggles (2001), 'Is Your Board Fit for the Global Challenge?' Corporate 
Governance in Europe.

Helbok, G. and M. Walker (2004), 'On the Nature and Rationality of Analysts' Forecasts Under Earnings Conservatism', The British Accounting Review, Vol. 36, No. 1 (March), pp. 45-77.

Huijgen C. and M. Lubberink. (2005), 'Earnings Conservatism, Litigation and Contracting: The Case of Cross Listed Firms', Journal of Business Finance \& Accounting, Vol. 32, No.7-8 (September), pp. 1275-1309.

Hung, M. (2000), 'Accounting Standards and Value Relevance of Financial Statements: An International Analysis', Journal of Accounting and Economics, Vol. 30, No. 3 (December), pp. 401-420.

Irvine, P. (2004), 'Analysts' Forecasts and Brokerage-Firm Trading', The Accounting Review, Vol. 79, No. 1 (January), pp. 125-149.

La Porta, R., F. Lopez-De-Silanes and A. Shleifer (1999), 'Corporate Ownership Around the World', Journal of Finance, Vol. 54, No. 2 (April), pp. 471-518.

Laporta R., F. Lopez-de Silanes, A. Shleifer and R. Vishny (1998), 'Law and Finance', Journal of Political Economy, Vol. 106, No. 6 (December), pp. 1113-1155.

Lara J.M.G, B. G. Osma and A. Mora. (2005), 'The Effect of Earnings Management on the Asymmetric Timeliness of Earnings', Journal of Business Finance \& Accounting, Vol. 32, No.3-4 (April), pp. 691-726.

Leuz, C., D. Nanda and P. Wysocki (2003), 'Earnings Management and Institutional Factors: An International Comparison', Journal of Financial Economics Vol. 69, No. 3 (September), pp. 505-527.

Lin, H. and M. McNichols (1998), 'Underwriting Relationships, Analysts' Earnings Forecasts and Investment Recommendations', Journal of Accounting and Economics, Vol. 25, No. 1 (February), pp. 101-128.

Lombardo, D. and M. Pagano (2002), 'Law and Equity Markets: A Simple Model', in J. McCahery, P. Moerland, T. Raaijmakers and L. Renneboog (eds.), Corporate Governance Regimes Convergence and Diversity (Oxford University Press).

Peek E., W. Buijink and L. Coppens (2004), 'Accounting Conservatism in the European Union: The Influence of Institutions and Incentives', Working paper, Maastricht University University.

Pope, P. and M. Walker (1999), 'International Differences in the Timeliness, Conservatism and Classification of Earnings', Journal of Accounting Research, Vol. 37, Supplement, 
pp. 53-87.

Raonic I., S. McLeay and I. Asimakopoulos (2004), 'The Timeliness of Income Recognition by European Companies: An Analysis of Institutional and Market Complexity', Journal of Business Finance Accounting, Vol. 31, Nos. 1\&2 (January), pp.115-148.

Richardson, S., S. Teoh and P. Wysocki (2004), 'The Walk-Down to Beatable Analysts Forecasts : The Role of Equity Issuance and Insider Trading Incentives', Contemporary Accounting Research, Vol. 21, No. 4 (Winter), pp.885-924.

Ryan S. and P. Zarowin (2003), 'Why has the Contemporaneous Linear Returns-Earnings Relation Declined?', The Accounting Review, Vol. 78, No. 2 (April), pp.523-553.

Watts, R. (2003), 'Conservatism in Accounting Part I: Explanations and Implications' Accounting Horizons, Vol.17, No. 3 (September), pp. 207-221. 
Table 1

Corporate Governance and Investor Protection

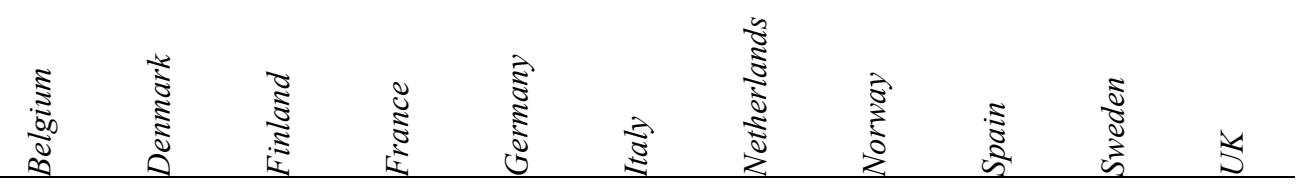

\section{Corporate Governance}

1 Board structure (two tier vs. unitary)

2 Separate supervisory and managerial leadership

\section{Investor Protection}

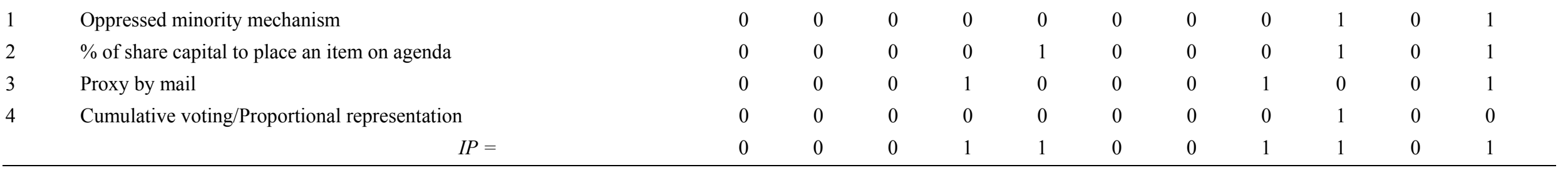

Notes:

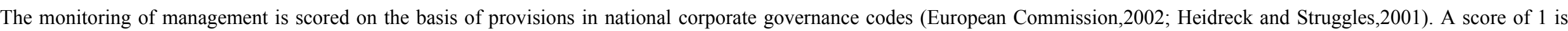

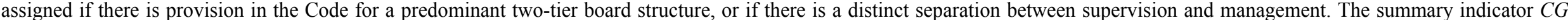

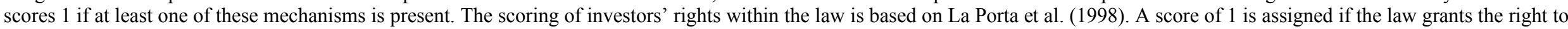

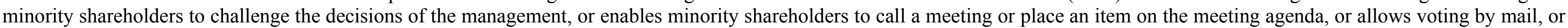
provides for proportional representation when appointing directors to the board. The summary indicator $I P$ scores 1 if at least one of these mechanisms is present. 
Table 2

\section{Descriptive Statistics}

\begin{tabular}{|c|c|c|c|c|c|c|c|}
\hline & \multirow[b]{2}{*}{$\begin{array}{l}\text { Number of } \\
\text { Observations }\end{array}$} & \multicolumn{3}{|c|}{ Closely Held Shares (\%) } & \multicolumn{3}{|c|}{ Share Price Changes } \\
\hline & & Mean & $\begin{array}{l}\text { Standard } \\
\text { Deviation }\end{array}$ & Median & Mean & $\begin{array}{l}\text { Standard } \\
\text { Deviation }\end{array}$ & Median \\
\hline Belgium & 493 & 52.31 & 17.63 & 53.11 & 0.0390 & 0.3806 & 0.0067 \\
\hline Denmark & 460 & 34.21 & 23.22 & 33.75 & 0.0960 & 0.4501 & 0.0209 \\
\hline Finland & 592 & 37.97 & 23.53 & 38.21 & 0.1505 & 0.5155 & 0.0576 \\
\hline France & 1971 & 51.30 & 22.94 & 53.28 & 0.1012 & 0.4453 & 0.0288 \\
\hline Germany & 1451 & 51.31 & 22.79 & 52.64 & -0.0156 & 0.4510 & -0.0643 \\
\hline Italy & 729 & 49.65 & 21.55 & 52.17 & 0.0599 & 0.4636 & -0.0263 \\
\hline Netherlands & 1065 & 43.61 & 24.96 & 42.79 & 0.1159 & 0.4426 & 0.0547 \\
\hline Norway & 666 & 40.21 & 22.27 & 40.37 & 0.1095 & 0.5123 & 0.0567 \\
\hline Spain & 742 & 45.30 & 23.26 & 48.25 & 0.1266 & 0.4210 & 0.0858 \\
\hline Sweden & 1000 & 35.09 & 21.96 & 32.47 & 0.1048 & 0.5085 & 0.0465 \\
\hline UK & 2600 & 20.07 & 19.29 & 15.31 & 0.1145 & 0.4649 & 0.0482 \\
\hline All Firms & 11769 & 39.92 & 25.06 & 40.10 & 0.0907 & 0.4637 & 0.0280 \\
\hline
\end{tabular}




\section{Table 2 (continued)}

\begin{tabular}{|c|c|c|c|c|c|c|c|c|c|}
\hline & \multicolumn{9}{|c|}{ Earnings Yield } \\
\hline & \multirow{3}{*}{\multicolumn{3}{|c|}{$\begin{array}{c}\text { Current Forecast } \\
\qquad F Y_{0} \\
\text { Standard }\end{array}$}} & \multirow{3}{*}{\multicolumn{3}{|c|}{$\begin{array}{l}\text { One Year Ahead Forecast } \\
\qquad F Y_{1} \\
\text { Standard }\end{array}$}} & \multirow{3}{*}{\multicolumn{3}{|c|}{$\begin{array}{l}\text { Two Years Ahead Forecast } \\
\qquad \mathrm{FY}_{2} \\
\text { Standard }\end{array}$}} \\
\hline & & & & & & & & & \\
\hline & & & & & & & & & \\
\hline & Mean & Deviation & Median & Mean & Deviation & Median & Mean & Deviation & Median \\
\hline Belgium & 0.0547 & 0.0445 & 0.0595 & 0.0704 & 0.0407 & 0.0691 & 0.0855 & 0.0478 & 0.0807 \\
\hline Denmark & 0.0580 & 0.0550 & 0.0570 & 0.0774 & 0.0480 & 0.0717 & 0.0918 & 0.0542 & 0.0850 \\
\hline Finland & 0.0574 & 0.0625 & 0.0535 & 0.0775 & 0.0559 & 0.0688 & 0.0969 & 0.0642 & 0.0855 \\
\hline France & 0.0520 & 0.0479 & 0.0530 & 0.0690 & 0.0428 & 0.0649 & 0.0829 & 0.0498 & 0.0771 \\
\hline Germany & 0.0339 & 0.0494 & 0.0369 & 0.0504 & 0.0392 & 0.0472 & 0.0644 & 0.0439 & 0.0578 \\
\hline Italy & 0.0433 & 0.0506 & 0.0419 & 0.0559 & 0.0447 & 0.0505 & 0.0702 & 0.0511 & 0.0610 \\
\hline Netherlands & 0.0781 & 0.0576 & 0.0809 & 0.0948 & 0.0516 & 0.0947 & 0.1103 & 0.0551 & 0.1091 \\
\hline Norway & 0.0606 & 0.0730 & 0.0626 & 0.0861 & 0.0575 & 0.0803 & 0.1047 & 0.0597 & 0.0983 \\
\hline Spain & 0.0708 & 0.0565 & 0.0699 & 0.0841 & 0.0481 & 0.0789 & 0.0980 & 0.0526 & 0.0921 \\
\hline Sweden & 0.0429 & 0.0609 & 0.0443 & 0.0621 & 0.0490 & 0.0552 & 0.0813 & 0.0561 & 0.0725 \\
\hline UK & 0.0656 & 0.0523 & 0.0673 & 0.0825 & 0.0459 & 0.0785 & 0.0969 & 0.0508 & 0.0900 \\
\hline All Firms & 0.0561 & 0.0559 & 0.0570 & 0.0733 & 0.0485 & 0.0691 & 0.0886 & 0.0539 & 0.0817 \\
\hline
\end{tabular}

Notes:

Firm-year observations from 1988 to 2002 are for listed companies domiciled in European countries for which the full set of institutional indicators given in Table 1 is available. The information required to calculate the percentage of closely held shares is taken from Worldscope.

The share price changes are ex-dividend returns based on Worldscope market capitalisation. To avoid problems arising from differences in 'per share' adjustment factors in different databases, earnings forecasts are calculated on an entity basis by multiplying I/B/E/S consensus EPS (for the current year and one and two years ahead) by the corresponding number of shares in issue given by $\mathrm{I} / \mathrm{B} / \mathrm{E} / \mathrm{S}$, then scaled by the Worldscope market capitalisation of the entity. All firms in the sample have a December year-end, and observations falling at the top and bottom $1 \%$ of the frequency distribution have been deleted. 
Table 3

Panel A

\section{Insitutional Arrangements, Ownership and Value Shocks Cross-Sectional Time Series Fixed Effects Diagnostics}

\begin{tabular}{|c|c|c|c|c|c|c|}
\hline & \multicolumn{3}{|c|}{ Negative Value Shocks } & \multicolumn{3}{|c|}{ Positive Value Shocks } \\
\hline & $F Y_{0}$ & $F Y_{1}$ & $F Y_{2}$ & $F Y_{0}$ & $F Y_{1}$ & $\mathrm{FY}_{2}$ \\
\hline Number of observations & 5281 & 5281 & 5278 & 6049 & 6061 & 6071 \\
\hline \multicolumn{7}{|l|}{$\mathrm{R}^{2}$ goodness of fit } \\
\hline Within & $15.03 \%$ & $16.54 \%$ & $12.74 \%$ & $3.92 \%$ & $8.01 \%$ & $10.17 \%$ \\
\hline Between & $27.77 \%$ & $34.59 \%$ & $25.40 \%$ & $20.19 \%$ & $9.57 \%$ & $3.14 \%$ \\
\hline Overall & $15.96 \%$ & $17.10 \%$ & $12.65 \%$ & $3.87 \%$ & $7.46 \%$ & $9.23 \%$ \\
\hline Model F-test & 58.03 & 65.01 & 47.88 & 15.35 & 32.82 & 42.76 \\
\hline \multicolumn{7}{|l|}{ Observations per group } \\
\hline Minimum & 8 & 8 & 8 & 32 & 32 & 32 \\
\hline Average & 352.1 & 352.1 & 351.9 & 403.3 & 404.1 & 404.7 \\
\hline Maximum & 864 & 863 & 863 & 859 & 861 & 859 \\
\hline \multicolumn{7}{|l|}{ Standard deviation } \\
\hline Fixed error component & 0.0120 & 0.0092 & 0.0100 & 0.0104 & 0.0100 & 0.011 \\
\hline Residual error component & 0.0482 & 0.0371 & 0.0412 & 0.0502 & 0.0463 & 0.0520 \\
\hline Fraction of variance due to fixed effect & $5.86 \%$ & $5.75 \%$ & $5.57 \%$ & $4.08 \%$ & $4.47 \%$ & $4.50 \%$ \\
\hline F-test of zero fixed error component & 15.36 & 13.12 & 13.36 & 16.67 & 18.27 & 18.63 \\
\hline
\end{tabular}




\section{Table 3}

\section{Panel B}

Insitutional Arrangements, Ownership and Negative Value Shocks

$$
\begin{aligned}
& F Y_{i, t+n}=\alpha_{0}+\alpha_{1} R_{i t}+\alpha_{2 k} I P C G_{k}+\alpha_{3 k} I P C G_{k} * R_{i t}+\alpha_{4} R_{i t} * O C_{i t}^{\prime} \\
& \quad+\alpha_{5 k} I P C G_{k} * O C_{i t}^{\prime}+\alpha_{6 k} I P C G_{k} * R_{i t} * O C_{i t}^{\prime}+\alpha_{7} M C_{i t}+u_{i t}
\end{aligned}
$$

\begin{tabular}{|c|c|c|c|c|c|c|}
\hline \multicolumn{7}{|c|}{ Panel A: Negative Value Shocks } \\
\hline Coeff. & $I P$ & $C G$ & Predicted sign & $F Y_{0}$ & $F Y_{1}$ & $F Y_{2}$ \\
\hline \multirow[t]{2}{*}{$\alpha_{0}$} & & & & 0.0612 & 0.0705 & 0.0831 \\
\hline & & & & $(17.82)$ & $(26.67)$ & $(28.37)$ \\
\hline \multirow[t]{2}{*}{$\alpha_{1}$} & & & $(+)$ decreasing & $0.0899 * * *$ & $0.0784 * * *$ & $0.0783^{* * *}$ \\
\hline & & & & $(7.87)$ & $(8.87)$ & $(8.02)$ \\
\hline \multirow[t]{6}{*}{$\alpha_{2}$} & 1 & 0 & & $0.0112 * * *$ & $0.0141 * * *$ & $0.0125 * * *$ \\
\hline & & & & $(2.98)$ & $(4.87)$ & $(3.88)$ \\
\hline & 0 & 1 & & $0.0096^{* * *}$ & $0.0142 * * *$ & $0.0166^{* * *}$ \\
\hline & & & & $(2.37)$ & $(4.54)$ & $(4.79)$ \\
\hline & 1 & 1 & & -0.0041 & -0.0069 & $-0.0102 * * *$ \\
\hline & & & & $(-0.90)$ & $(-1.96)$ & $(-2.63)$ \\
\hline \multirow[t]{6}{*}{$\alpha_{3}$} & 1 & 0 & (no effect) & 0.0087 & -0.0022 & -0.0139 \\
\hline & & & & $(0.71)$ & $(-0.23)$ & $(-1.31)$ \\
\hline & 0 & 1 & (no effect) & 0.0241 & 0.0142 & 0.0117 \\
\hline & & & & $(1.83)$ & $(1.40)$ & $(1.04)$ \\
\hline & 1 & 1 & (no effect) & 0.0034 & -0.0175 & $-0.0326^{* * *}$ \\
\hline & & & & $(0.24)$ & $(-1.64)$ & $(-2.75)$ \\
\hline \multirow[t]{2}{*}{$\alpha_{4}$} & & & $(-)$ & $-0.0022 * * *$ & $-0.0013 * * *$ & $-0.0012 * *$ \\
\hline & & & & $(-3.80)$ & $(-2.92)$ & $(-2.50)$ \\
\hline \multirow[t]{6}{*}{$\alpha_{5}$} & 1 & 0 & & $0.0004 * *$ & $0.0003 * *$ & 0.0003 \\
\hline & & & & $(2.10)$ & $(2.08)$ & $(1.96)$ \\
\hline & 0 & 1 & & 0.0003 & $0.0004 * * *$ & $0.0004 * *$ \\
\hline & & & & $(1.71)$ & $(2.81)$ & $(2.42)$ \\
\hline & 1 & 1 & & 0.0000 & 0.0001 & 0.0002 \\
\hline & & & & $(0.11)$ & $(0.67)$ & $(0.96)$ \\
\hline \multirow[t]{6}{*}{$\alpha_{6}$} & 1 & 0 & $(+)$ & $0.0023 * * *$ & $0.0012 * * *$ & $0.0011^{* *}$ \\
\hline & & & & $(3.76)$ & $(2.66)$ & $(2.21)$ \\
\hline & 0 & 1 & $(+)$ & $0.0017 * * *$ & $0.0014 * * *$ & $0.0013 * *$ \\
\hline & & & & $(2.68)$ & $(2.90)$ & $(2.41)$ \\
\hline & 1 & 1 & $(+)$ & 0.0007 & 0.0008 & 0.0010 \\
\hline & & & & $(1.12)$ & $(1.53)$ & $(1.83)$ \\
\hline
\end{tabular}


Table 3

Panel C

Insitutional Arrangements, Ownership and Positive Value Shocks

$$
\begin{aligned}
& F Y_{i, t+n}=\alpha_{0}+\alpha_{1} R_{i t}+\alpha_{2 k} I P C G_{k}+\alpha_{3 k} I P C G_{k} * R_{i t}+\alpha_{4} R_{i t} * O C_{i t}^{\prime} \\
& \quad+\alpha_{5 k} I P C G_{k} * O C_{i t}^{\prime}+\alpha_{6 k} I P C G_{k} * R_{i t} * O C_{i t}^{\prime}+\alpha_{7} M C_{i t}+u_{i t}
\end{aligned}
$$

\begin{tabular}{|c|c|c|c|c|c|c|}
\hline \multicolumn{7}{|c|}{ Panel B: Positive Value Shocks } \\
\hline Coeff. & $I P$ & $C G$ & Predicted sign & $F Y_{0}$ & $F Y_{1}$ & $F Y_{2}$ \\
\hline \multirow[t]{2}{*}{$\alpha_{0}$} & & & & 0.0581 & 0.0707 & 0.0833 \\
\hline & & & & (20.19) & $(26.62)$ & $(27.90)$ \\
\hline \multirow[t]{2}{*}{$\alpha_{1}$} & & & $(+)$ increasing & 0.0064 & $0.0152 * * *$ & $0.0275^{* * *}$ \\
\hline & & & & $(1.18)$ & $(3.04)$ & $(4.91)$ \\
\hline \multirow[t]{6}{*}{$\alpha_{2}$} & 1 & 0 & & $0.0126^{* * *}$ & $0.0124 * * *$ & $0.0114 * * *$ \\
\hline & & & & $(4.01)$ & $(4.28)$ & $(3.5)$ \\
\hline & 0 & 1 & & $0.0156^{* * *}$ & $0.0170 * * *$ & $0.0175^{* * *}$ \\
\hline & & & & $(4.64)$ & $(5.48)$ & $(5.04)$ \\
\hline & 1 & 1 & & -0.0066 & -0.0055 & -0.0068 \\
\hline & & & & $(-1.62)$ & $(-1.47)$ & $(-1.63)$ \\
\hline \multirow[t]{6}{*}{$\alpha_{3}$} & 1 & 0 & (no effect) & 0.0021 & 0.0075 & 0.0066 \\
\hline & & & & $(0.36)$ & $(1.38)$ & $(1.09)$ \\
\hline & 0 & 1 & (no effect) & 0.0011 & 0.0015 & 0.0026 \\
\hline & & & & $(0.17)$ & $(0.27)$ & $(0.41)$ \\
\hline & 1 & 1 & (no effect) & -0.0079 & -0.0127 & -0.0149 \\
\hline & & & & $(-1.02)$ & $(-1.78)$ & $(-1.87)$ \\
\hline \multirow[t]{2}{*}{$\alpha_{4}$} & & & (no effect) & -0.0001 & 0.0000 & 0.0000 \\
\hline & & & & $(-0.52)$ & $(-0.19)$ & $(-0.12)$ \\
\hline \multirow[t]{6}{*}{$\alpha_{5}$} & 1 & 0 & & -0.0002 & -0.0001 & 0.0000 \\
\hline & & & & $(-1.38)$ & $(-0.66)$ & $(-0.22)$ \\
\hline & 0 & 1 & & 0.0001 & 0.0002 & 0.0002 \\
\hline & & & & $(0.87)$ & $(1.40)$ & $(1.07)$ \\
\hline & 1 & 1 & & -0.0002 & -0.0002 & -0.0002 \\
\hline & & & & $(-1.12)$ & $(-1.13)$ & $(-0.97)$ \\
\hline \multirow{6}{*}{$\alpha_{6}$} & 1 & 0 & (no effect) & 0.0002 & 0.0000 & 0.0000 \\
\hline & & & & $(0.74)$ & $(0.01)$ & $(-0.02)$ \\
\hline & 0 & 1 & (no effect) & 0.0001 & 0.0000 & 0.0000 \\
\hline & & & & $(0.39)$ & $(0.08)$ & $(-0.06)$ \\
\hline & 1 & 1 & (no effect) & 0.0002 & 0.0003 & 0.0002 \\
\hline & & & & $(0.60)$ & $(0.85)$ & $(0.47)$ \\
\hline
\end{tabular}


Notes:

$F Y_{i, t+n}$ is the expected earnings of the $i^{\text {th }}$ firm either for the current year $(n=0)$, or for one year ahead $(n=1)$, or two years ahead $(n=2)$, scaled by market capitalisation at the beginning of the current year; $R_{i t}$ is the annual change in market capitalisation of the $i^{\text {th }}$ firm deflated by the market capitalisation at the beginning of the current year. $O C^{\prime}$ is the ownership effect that is exogenous to institutional arrangements. The intercept $\alpha_{0}$ is estimated when investor protection provisions $(I P)$ and corporate governance arrangements $(C G)$ are both absent, i.e. $I P C G_{k}=(0,0)$. The other levels of this factor are: $(1,1)$ if the firm operates in an environment where strong investor protection is imposed by law and where managerial monitoring is also provided for in the local corporate governance code; $(1,0)$ if there is strong investor protection but no monitoring; $(0,1)$ if there is monitoring but investor protection is weak. $* *$ denotes statistical significance at $5 \%$ and $* * *$ at $1 \%$ or less. 